\title{
FENOMENA KONVERSI AGAMA DI KOTA PEKANBARU (KAJIAN TENTANG POLA DAN MAKNA)
}

\author{
Khairiah \\ Prodi Studi Agama-agama Fakultas Ushuluddin UIN Suska Riau \\ Email:khairiah@uin-suska.ac.id
}

\begin{abstract}
Abstrak
Tulisan ini mengemukakan hasil penelitian yang dilakukan terhadap konversi agama yang terjadi di Kota Pekanbaru dari tahun 2013-2017. Konversi yang menjadi fokus dalam penelitian ini adalah konversi dari agama non Islam ke agama Islam. Ada banyak hal menarik dari konversi agama sehingga banyak alasan untuk dapat diteliti baik tentang pola dan makna konversi itu sendiri bagi konversen (pelaku)nya. Penyebab terjadinya konversi agama pada masyarakat kota pekanbaru dapat dilihat dari berbagai faktor yang ada seperti: faktor sosial, pendidikan, psikologi, agama, dan ekonomi. Melihat fenomena yang ada peneliti menyimpulkean bahwa konversi agama di Pekanbaru mengalami peningkatan yang cukup signifikan dalam lima tahun terakbir ini yakni dari tahun 2013-2017. Pola umum dalam peristiva konversi agama di Pekanbaru antaralain; konversi yang dilatarbelakangi pernikahan. Fenomena seperti ini bisa terjadi pada pibak wanita (istri) atau lakiIaki (suami). Seorang anak yang pindah agama karena keretakan keluarganya. Seorang pekerja yang rela mengubah keyakinan karena tertarik dengan hijab. Seorang pemuda yang tertarik pindah agama karena mendengar suara azan. Seorang wanita yang tertarik, pindah agama karena membaca dan menonton film Hidayah. Fenomena konversi agama merupakan hal yang dapat mengubah pendirian atau keyakinan seseorang dari agama sebelumnya pindah ke agama lain. Fenomena ini dapat meresabkan hati dan keyakinan dari setiap pemeluk agama.Termasuk pemeluk agama yang berada di Kota Pekanbaru.
\end{abstract}

Kata kunci; Konversi, agama, Pekanbaru

\section{Pendahuluan}

Di Indonesia, fenomena perpindahan agama sudah tidak asing lagi dalam kehidupan sehari-hari, baik itu perpindahan agama dari Hindu, Budha, Kristen, Konghucu ke Islam ataupun sebaliknya. Tidak sedikit orang berpindah agama dengan alasan menikah. Bagi pasangan yang berbeda agama dan ingin menikah, harus merelakan salah satu kepercayaan yang mereka anut, untuk mempermudah proses pernikahan.

Faktor keretakan keluarga, ketidakserasian, dan lainnya dapat menyebabkan seseorang mengalami tekanan batin sehingga terjadi konversi agama. Untuk meredakan tekanan batin yang menimpa diri, seorang individu mengubah status hidupnya. Perubahan status terutama yang berlangsung secara mendadak akan banyak mempengaruhi 
terjadinya konversi agama, misalnya perceraian, keluar dari sekolah atau sebuah perkumpulan, perubahan pekerjaan, menikah dengan orang yang berlainan agama dan sebagainya.

Jika hal ini dikaitkan dengan teori bahwa secara kultural masyarakat Indonesia yang dikenal sebagai masyarakat religious, maka dalam nilai-nilai agama sebenarnya terdapat nilai yang sangat efektif untuk membangun karakter masyarakat yang beradab di mana sosialisasi nilai-nilai substansial dalam agama dapat ditanamkan melalui lembagalembaga keagamaan. Tentu saja ini akan sulit diaplikasikan pada masyarakat beragama yang merupakan hasil dari konversi agama (Khotimah, 2014).

Pekanbaru merupakan kota metropolitan yang sangat heterogen. Migran yang pindah dan menetap di kota ini berasal dari latar belakang yang berbeda-beda, baik dari segi suku, adat istiadat, dan agama. Kemajuan ilmu pengetahuan dan teknologi, menyuburkan mental materialis dan hedonis.Timbulnya masalah kemiskinan, penganguran, menyebabkan goncangan dan banyaknya gangguan psikis manusia, telah memperkokoh eksistensi agama sebagai alternatif - yang pada prakteknya terlupakan - dalam mengatasi persoalanpersoalan ini (Aripuddin, 2012).

Melihat fenomena yang ada peneliti menyimpulkan bahwa konversi agama di Pekanbaru mengalami peningkatan yang cukup signifikan dalam tiga tahun terakhir ini yakni dari tahun 2013-2017. Fakta konversi agama yang terjadi di kota Pekanbaru menarik untuk diteliti dari sisi maknanya bagi konversen.

Lebih dari itu yang menjadi akar fundamental dari tindakan konversi itu sendiri adalah bagian internal psikologis yang mendorong seorang individu mengambil keputusan untuk melakukan tindakan konversi. Kajian ini menjadi penting untuk menemukan motif yang sesungguhnya dibalik suatu tindakan konversi masalah makna dari peristiwa konversi itu sendiri bagi konversen.

Selanjutnya tidak kalah penting adalah upaya untuk menggali makna yang dihayati seorang individu terkait tindakan konversi yang dijalaninya. Masalah makna adalah masalah cara pandang seorang individu dalam menafsirkan peristiwa kehidupan. Sejauh mana pendalaman makna yang didapat oleh sesorang sepanjang penafsirannya akan sesuatu peristiwa kehidupan akan sangat berpengaruh pada penilaian individu tersebut terhadap urgensi dari setiap langkah dan tindakan yang diambilnya dalam hidup.

Berdasarkan latar belakang diatas, maka penelitian ini akan menjawab persoalan apa motif dibalik tindakan konversi yang terjadi di kalangan warga kota Pekanbaru? Dan apa makna konversi agama bagi para pelakunya di kalangan warga di kota Pekanbaru? 
Pentingnya penelitian ini, untuk mengetahui makna konversi bagi pelaku dan tokoh -tokoh agama sehingga dapat menjadi antisipasi dalam membangun interaksi yang baik antar umat beragama. penelitian ini akan melihat lebih dekat makna yang dihayati seorang individu sehingga ia melakukan konversi, serta bagaimana para tokoh agama melihat fenomena tersbut.

Penelitian ini sangat signifikan dalam rangka sebagai wujud partisipasi dalam menciptakan pembangunan bangsa. Melalui wujud kedamaian, kehidupan yang aman dan tidak ada gesekan konflik maka pemerintah akan dapat mewujudkan pembangunan dengan aman tanpa ada gangguan konflik yang dapat memecah belah kesatuan bangsa. Dengan demikian diharapkan dapat memberikan kontribusi untuk para pengambil kebijakan khususnya di Kota Pekanbaru yang memiliki otoritas dalam mengatur kehidupan umat beragama. Selanjutnya penelitian akan melahirkan sebuah pemahaman baru dalam mengantisipasi perubahan yang terjadi dalam hubungan sosial antar individu maupun antar kelompok dalam masyarakat sehingga terjadinya konversi tidak akan menimbulkan gejolak social.

Penelitian ini dilakukan di 12 kecamatan di wilayah Kota Pekanbaru. Karena penelitian ini memotret fenomena sosial maka metode yang digunakan adalah metode kualitatif dengan pendekatan deskriptif-interprtatif. Metode kualitatif ini penulis pilih agar dapat memperoleh keterangan-keterangan yang detail dan mendalam mengenai makna dari peristiwa konversi yang dialami dan dijalani konversen yang menjadi objek dari penelitian ini. Pemilihan penulis terhadap metode penelitian kualitatif adalah sebagaimana pendapat Patton (1980:43) dalam bukunya "Qualitative Evaluation Methods, yang menyatakan bahwa data kualitatif hanya bisa didapat dengan mendekati secara fisik dan psikologis fenomena yang dikaji. Karena itu alasan menggunakan metode ini supaya dapat memahami makna tindakan para responden melalui perkataan mereka sendiri.

Pendekatan kualitatif adalah pendekatan yang dilakukan dengan mengumpulkan informasi dalam bentuk kata-kata atau keterangan-keterangan dengan tidak memerlukan perhitungan angka. Dengan metode kualitatif, peneliti mencoba memahami fenomena sosial dari sudut pandang partisipan. Dalam hal ini adalah orang-orang yang diwawancarai, diobservasi, dimintai data, pendapat dan pemikiran terkait objek penelitian.

Sementara pendekatan deskriptif interpretative dilakukan untuk mempelajari secara intensif tentang makna tindakan konversi yang dilakukan oleh kenversen dari sudut rasa terdalam mereka. Dalam penelitian kualitatif kehadiran peneliti di lapangan adalah mutlak diperlukan karena peneliti berfungsi sebagai instrumen kunci dan 
sekaligus sebagai pengumpul data utama. Hal ini dilakukan karena, jika memanfaatkan alat yang bukan manusia dan tanpa persiapan terlebih dahulu, maka sangat tidak mungkin untuk mengadakan penyesuaian terhadap kenyataan-kenyataan yang ada di lapangan.Selain itu hanya manusia yang dapat berhubungan dengan responden atau obyek utama, dan hanya manusialah yang mampu memahami kaitan kenyataan-kenyataan di lapangan.

Sebagai ikhtiar untuk mengetahui fakta di lapangan, peneliti menggali data dari sumber-sumber utama yang terlibat langsung dengan peristiwa konversi, yakni; , Konversen, Pihak KUA, dan warga/tentangga melalui teknik observasi dan wawancara dengan jenis wawancara mendalam (deep interview). Selain itu peneliti juga aktif mengakses data dalam bentuk dokumen Surat Keterangan Masuk Islam (SKMI) yang diterbitkan oleh KUA

Karena penelitian ini bersifat kualitatif, peneliti menerapkan purposive sampling di mana sample diambil bukan dari populasi melainkan sesuai dengan tujuan penelitian. Dalam purposive sampling peneliti cenderung memilih responden yang dapat dipercaya untuk menjadi sumber data serta mengetahui masalah secara mendalam. Dengan demikian penetapan responden bukan ditentukan oleh pemikiran bahwa ia representatif terhadap populasinya melainkan responden harus representatif terhadap informasi yang diperlukan. Adapun yang menjadi responden adalah konversen dan tokoh tokoh agama di Pekanbaru.

Peneliti memfokuskan observasi dan wawancara untuk memperluas dan memperjelas makna yang terkandung dalam domain tertentu dengan menggunakan taxonomic analysis. Taxonomic analysis digunakan untuk mengungkap alasan mengapa dan bagaimana tentang makna yang terkandung, kemudian makna tersebut disusun secara sistematis. Berdasarkan jenis dan bentuk data tersebut, makna teknik analisis data dalam penelitian ini menggunakan jenis deskriptif melalui tiga alur kegiatan yaitu: (1) mereduksi data, (2) penyajian data, dan (3) penarikan simpulan.

\section{Kajian Pustaka}

Banyak kajian yang telah dibuat terkait dengan konversi agama, baik secara teoretis maupun praktis.Teori-teori konversi dikaji ahli psikologi baik barat maupun Indonesia.William James, Walter Huston Clark, Marx Heinrich, Zakiah Daradjat dan Ramayulis, merupakan para ahli antropologi agama dan psikologi agama yang memberikan landasan teoretis tentang makna, faktor dan proses konversi serta dampak dampaknya dalam perubahan sosial dan kebuadayaan.

Dalam Konteks kajian tentang perkembangan Islam di Asia Tenggara, salah satu bagian yang paling menarik dari ekposisi sejarah total Reid adalah berkenaan dengan apa yang disebutnya sebagai revolusi keagamaan (religious 
revolution). Dalam kajian tentang revolusi keagamaan ini, penting dicatat, Reid tidak membatasi pembahasannya pada penyebaran Islam, tetapi juga mencakup tentang penyebaran Kristen. Dilihat "keagamaan" ini adalah bahwa lebih dari seperdua penduduk Asia Tenggara melakukan konversi keagamaan kepada Islam dan Kristen pada "masa perdagangan". Konversi masif kepada kedua agama wahyu yang terjadi pada masa itu menurut Reid, mempunyai nilai penting yang bersifat permanen (Azra, 1999).

Dalam membahas "revolusi keagamaan" atau konversi massal, Reid memang tidak membahas secara rinci penyebaran Islam (dan juga Kristen) sebelum tahun 1450. Tetapi argumennya tentang "Lebih seperdua penduduk Asia Tenggara beralih kepada Islam dan Kristen" secara implisit mengakui bahwa kedua agama ini telah ada di "negerinegeri” bawah angin sebelum kurun 1450. Bahkan selanjutnya Reid menyatakan secara eksplisit bahwa Islam (baik Sunni maupun Syi'ah) dan Kristen (baik Katolik maupun Nestorian), Yahudi, dan berbagai kultus Hindu maupun Budha telah terwakili di Asia tenggara sejak milenium pertama, terutama melalui pedagang dan pengembara.

Walter Houston Clark mendefenisikan konversi agama sebagai semacam pertumbuhan atau perkembangan spiritual yang mengandung perubahan arah yang signifikan, dalam sikap terhadap ajaran dan perilaku agama. Lebih jelas dan lebih tegas lagi, konversi agama menunjukkan bahwa suatu perubahan emosi yang tibatiba ke arah mendapat hidayah Allah secara mendadak, telah terjadi, yang mungkin saja sangat mendalam atau dangkal.

Max Heinrich mengatakan bahwa konversi agama adalah suatu tindakan di mana seseorang atau sekelompok orang masuk atau berpindah ke suatu sistem kepercayaan atau perilaku yang berlawanan dengan kepercayaan sebelumnya.

Menurut William James (dalam Daradjat, 1979), konversi agama banyak menyangkut masalah kejiwaan dan pengaruh lingkungan tempat berada.

Konversi agama sebagai semacam pertumbuhan atau perkembangan spiritual yang mengandung perubahan arah yang cukup berarti, dalam sikap terhadap ajaran dan tindakan agama. Konversi agama menunjukkan bahwa suatu perubahan emosi yang tiba-tiba kearah mendapat hidayah Allah SWT secara mendadak, telah terjadi, yang mungkin saja sangat mendalam atau dangkal, dan mungkin pula terjadi perubahan tersebut secara berangsur-angsur.

William James mengatakan konversi agama sebagai: berubah, digenerasikan, untuk menerima kesukaan, untuk menjalani pengalaman beragama, untuk mendapatkan kepastian adalah banyaknya ungkapan pada proses baik itu berangsur- 
angsur atau tiba-tiba yang dilakukan secara sadar dan terpisah-pisah kurang bahagia dalam konsekuensi penganutnya yang berlandaskan kenyataan beragama.

Dorongan beragama pada orang dewasa didasarkan kepada penalaran yang logis, sehingga ia akan mempertimbangkan sepenuhnya menurut logika. Keberagamaan pada masa dewasa sudah menjadi hal yang mantap. Tetapi lebih berdasarkan kepada kepuasan atau kenikmatan yang diperoleh dari pelaksanaan ajaran agama tersebut. Dan ini termanifestasi dalam tingkah laku moral yang tinggi dalam kehidupan seharihari.

Kondisi demikian akan memunculkan kematangan dalam beragama. Perkembangan keagamaan seseorang untuk sampai pada tingkat kematangan beragama dibutuhkan proses yang panjang (Agusrianto, 2009).

Zakiah Daradjat dalam buku Ilmu Jiwa Agama (1984) mengungkap faktor-faktor konversi agama, sebagai berikut:

1. Adanya pertentangan batin dan ketegangan perasaan, orang-orang yang gelisah, di dalam dirinya bertarung dengan berbagai persoalan, yang kadang-kadang dia merasa tidak berdaya menghadapi persoalan itu, mudah mengalami konversi agama.

2. Pengaruh dari tradisi agama, di antara faktor-faktor penting dalam riwayat konversi itu, adalah pengalaman- pengalaman yang mempengaruhinya sehingga terjadi konversi tersebut.

3. Ajakan atau sugesti, banyak pula terbukti bahwa di antara peristiwa konversi agama terjadi karena pengaruh sugesti dan bujukan dari luar.

4. Faktor-faktor emosi, orang yang emosionil mudah kena sugesti apabila ia sedang mengalami kegelisahan.

5. Kemauan, kemauan seseorang itu sendiri untuk memeluk kepercayaan yang lain.

Pendekatan kasuistik tentang konversi agama dapat ditemukan dalam penelitian dan tulisan jurnal ilmiah. Athisa88 dalam tulisan blognya berjudul; Fenomena Konversi Agama di Bali menjelaskan pola, faktor dan dampak dari konversi dari agama Hindu ke Kristen yang terjadi secara agak massive akhir akhir ini di Bali. Salah satu penyebabnya menurut Athisa adalah masalah ketidakpuasan terhadap hukum adat.

Belum ada kajian tentang konversi agama di Pekanbaru yang secara spesifik mengkaji motif dan makna tindakan konversi dari sudut pandang pelakunya. Dalam konteks inilah peneliti mengambil langkah untuk mengkaji hal tersebut.

\section{Kerangka Teori}

Penelitian ini berpijak pada pemahaman terhadap konversi agama sebagai sebuah fakta sosial yang berlangsung di masyarakat. Baik faktor eksternal maupun internal sama-sama 
menjadi penting dalam proses konversi. Terjadinya perubahan-perubahan dalam hubungan sosial pasca konversi antar individu dengan individu, individu dengan kelompok maupun kelompok dengan kelompok, berpotensi mengakibatkan goncangan-goncangan sosial. Maka pemahaman akan fenomena konversi dan makna di balik fenomena tersebut bagi konversen adalah sangat penting sebagai langkah awal untuk mengantisipasi goncangan-goncangan sosial yang mungkin terjadi.

Konversi berasal dari kata "conversio" yang berarti tobat, pindah, berubah (agama). Dalam kamus bahasa Inggris, verb atau kata kerja "convert" berarti merubah, mengubah,dan orang yang masuk agama lain, muallaf (Echols dan Shadily, 2012).

Kata conversion mengandung pengertian berubah dari suatu keadaan atau dari suatu agama ke agama lain (change from one state, from one religion to another) (Yelli, 2012). Berdasarkan kata di atas dapat disimpulkan bahwa konversi agama mengandung pengertian bertobat, berubah agama, berubah keyakinan, berbalik pendirian terhadap ajaran agama atau masuk ke dalam agama.

Kehidupan sebuah masyarakat pada umumnya akan mengalami yang namanya perubahan, baik hal yang negatif maupun positif. Perubahan sosial adalah sebagai bagian dari perubahan kebudayaan, hal demikian mempakan sesuatu yang wajar. Salah satu perubahan yang terdapat dalam pembahan sosial itu adalah perubahan agama, dari sistem keagamaan satu beralih atau berpindah ke sistem keagamaan yang lain (Soekanto, 1990). Dalam istilah sosiologi agama, hal tersebut sering disebut dengan kata konversi agama.

Konversi agama merupakan hal yang wajar ketika orang menyadari bahwa beragama adalah kebebasan setiap individu dalam suatu masyarakat. Kebebasan beragama merupakan hak asasi manusia yang sebenarnya tidak boleh diganggu gugat oleh siapapun. Negara pun menjamin akan kebebasan tersebut. Jelas dikatakan dalam UUD 1945, Pasal 29 ayat 2 yang berbunyi "Negara menjamin kemerdekaan tiap-tiap penduduk untuk memeluk agamanya masing-masing dan untuk beribadat menurut agamanya dan kepercayaannya masing-masing".

Seharusnya UUD 1945 ini dipegang teguh oleh warga negaranya, sehingga permasalahan yang ditimbulkan ketika orang melakukan konversi agama adalah permasalahan negara dengan masyarakatnya. Dalam hal ini negara seharusnya memberi perlindungan dan keadilan jika sesuatu yang negatif terjadi terhadap pelaku konversi agama. Masyarakat pun diajar untuk menyadari makna toleransi, tenggang rasa, saling menghormati, menghargai, sehingga dapat menghindari tindak kekerasan, diskriminasi dan hal-hal yang memgikan 
serta memberatkan pelaku konversi tersebut.

Indonesia merupakan negara yang multi religius dan multikultural, artinya banyak agama banyak budaya dari berbagai daerah. Maka kesadaran pluralisme agama pada masyarakat sangat penting untuk saling menumbuhkan sikap toleran, menghargai dan menghormati pemeluk agama satu dengan yang lain.

Kesadaran pluralitas akan menolong seseorang menyadari bahwa sikap superioritas tidak bermanfaat untuk mengerti orang lain lebih baik, sebab Allah mengasihi semua manusia tanpa terkecuali, dan karenanya harus memahami sesama atau menjadi sahabat bagi saudara-saudara kita yang berkepercayaan lain.(DamaPuter, 1995)

Pluralisme agama bukan berarti pencampuran atau sinkretisme, sebab keunikan masing- masing agama tetap dapat dipertahankan dan dapat dikomunikasikan dan bukan untuk diperbandingkan. Keterbukaan semacam ini menumbuhkan perdamaian dan toleransi dan bukan pada tempatnya lagi saling menghujat, menyalahkan apalagi membunuh (Abdullah, 1999). Kesadaran ini sangat penting dimiliki oleh semua masyarakat Indonesia demi terciptanya kondisi yang harmonis, di tengah-tengah segala perbedaan yang ada; baik suku, ras, terutama agama.
Pada bagian ini penulis akan memaparkan beberapa teori yang relevan untuk memahami fenomena konversi agama di Dusun Bukitsari Bali. Namun demikian penulis hanya akan menggunakan satu dari beberapa teori yang sesuai dengan kebutuhan penelitian. Adapun teori tersebut adalah sebagai berikut:

Thomas F. O’Dea (1987:105-119) berpandangan bahwa dalam sebuah tatanan masyarakat terdapat sebuah kondisi dan gaya hidup yang tidak sama yang mana melahirkan pandangan, kebutuhan, tanggapan dan struktur motivasi yang beraneka ragam. Beberapa prinsip keagamaan akan menunjukkan secara jelas kaitan konkret antara kebutuhan dan pandangan kelompok tertentu ketimbang kelompok yang lain yang kadangkala kepentingannya tidak tercermin sama sekali. Sebagai contoh soal pandangan kekristenan bahwa kekalahan Yesus yang duniawi dalam arti luas dianggap kemenangan dari iblis dan kematian ternyata akan memiliki daya tarik yang lebih besar bagi beberapa kelas dan lapisan dibanding kelas lain. Dengan demikian kebhinekaan kelompok dalam masyarakat akan mencerminkan perbedaan jenis kebutuhan keagamaan.

Masyarakat bukan hanya sekedar sebuah struktur sosial tetapi juga merupakan sebuah proses sosial yang kompleks. Dalam proses tersebut dapat timbul perubahan yang begitu cepat dan mengakibatkan tampilnya bentuk - 
bentuk baru serta mengganggu struktur yang sudah mapan. Hancumya bentuk bentuk sosial dan kultural yang telah mapan dan tampilnya bentuk-bentuk baru merupakan suatu proses yang berkesinambungan.

Dengan demikian jelas berbagai ragam kelompok yang ada dalam masyarakat dipengaruhi oleh berbagai perubahan sosial yang dimaksudkan O'Dea meminjam istilah Durkheim sebagai keadaan "anomi" yaitu: menunjukan keadaan disorganisasi sosial yang mana berbagai bentuk sosial dan kultur yang telah mapan ambruk. Dia berbicara tentang dua aspek dari masalah ini:

Pertama, hilangnya solidaritas yaitu apabila kelompok -kelompok lama, setiap individu mendapatkan rasa aman dan respon cenderung ambruk. Kedua, hilangnya konsensus yaitu tumbangnya persetujuan terhadap nilai nilai dan norma-norma yang memberikan arah dan makna bagi kehidupan kelompok. Durkheim memandang hal ini sebagai dua sisi dari satu proses disorganisasi.

Dalam masyarakat pola-pola sosial tampil karena manusia membutuhkannya, dan apabila pola yang demikian itu mengalami desintegrasi, maka manusia berusaha mencari jalan ke luar dari kekacauan dan kebingungan yang dihadapinya. Karena pengalaman anomi merupakan pengalaman yang mengecewakan, maka manusia bisa berbalik agresif menentang sumber-sumber nyata atau khayal dari kesukaran tersebut.

Akhimya mereka terlibat dalam permasalahan masyarakat dan berusaha mendapatkan makna baru, stratifikasi sosial dan doktrin keagamaan mengungkapkan bahwa kondisi kehidupan mempengaruhi kecenderungan agama manusia dan kondisi kehidupan memiliki korelasi yang cukup berarti dengan fakta stratifikasi sosial disemua masyarakat. Namun perkembangan ide, nilai dan praktek tertentu di suatu masyarakat dapat mempengaruhi semua kelas, strata dan kelompok yang ada dalam masyarakat tersebut.

Contoh sederhana yang dikemukakan Weber tentang kaum buruh industri seperti juga yang diungkapkan Marx, kaum proletar yang tidak memiliki kelas cenderung mencari agama sebagai solusi mengatasi ketidakberdayaan mereka.

Weber secara umum berbicara tentang kaum elit dan yang tidak memiliki hak istimewa. Ide-ide seperti keselamatan, dosa, dan kerendahan hati sebenarnya bagi kelas yang memiliki status sosial tinggi dan yang memiliki privilese ekonomi akan kurang mengembangkan gagasan keselamatan. Sebaliknya mereka memanfaatkan fungsi agama sebagai pengabsah pola kehidupan dan kondisi mereka di dunia. Kemudian 
kebalikan dari hal tersebut bagi kelas yang tidak mempunyai hak istimewa atau yang sudah tergusur menunjukan kecenderungan untuk merangkul dan mengembangkan agama -agama penyelamat, menerima pandangan rasional, dan menerima tentang persamaan derajat.

Hendropuspito (1984:78) dalam memahami kata "masuk agama" adalalah suatu pengertian yang tidak asing lagi bagi orang Indonesia. Pengertian atau gambaran masuk agama adalah ada orang yang dulunya belum beragama sama sekali kemudian menerima suatu agama. Kemudian ada orang yang sudah memeluk agama tertentu kemudian pindah ke agama lain. Dalam hal ini kata "masuk agama" sama artinya dengan "pindah agama '. Kata Latin "conversio" Iebih tepat untuk digunakan dalam arti kata "masuk agruna' dan 'berpindah agama". Kata Inggris "conversion" dapat diberi arti yang sama seperti di atas. Misalnya berpindahnya seorang pemeluk Agama Hindu atau Kristen ke agama Islam disebut dengan kata "conversion". Yang jelas bahwa kata "conversio" dan "conversion" mempunyai arti lebih luas: berbalik;bertobat; kembali; masuk ke dalam agama.

Menurut Heirich (dalam Dister, 1994:109-110) konversi agama adalah suatu tindakan dengan mana seseorang atau kelompok masuk atau berpindah ke suatu sistem kepercayaan atau perilaku yang berlawanan dengan kepercayaan sebelumnya. Konversi juga dapat diberi deskripsi sebagai suatu tindakan dengan mana seseorang atau kelompok mengadakan perubahan yang mendalam mengenai pengalaman dan tingkat keterlibatannya dalam agamanya ke tingkat yang lebih tinggi. Dalam penelitian ini peneliti akan menggunakan pengertian yang pertama dimana kata konversi dipahami sebagai kata masuk atau pindah agama.

Konversi agama tidak terjadi dengan sendirinya tanpa ada faktor penyebabnya. Dari kalangan teologi menyebutnya faktor pengaruh ilahi. Faktor kedua datang dari kalangan psikologi: pembebasan dari tekanan batin. Faktor ketiga dari kalangan pendidikan: situasi pendidikan. Faktor keempat dari kalangan sosial: aneka pengamh social (Heirich, 2008).

Heirich (2008) berpendapat bahwa pengaruh sosial mempakan salah satu alasan mengapa seseorang dapat melakukan konversi agama. Mengapa demikian? Pertama, karena adanya pergaulan antar pribadi yang saling mempengaruhi. Kedua, orang diajak masuk kumpulan yang sesuai dengan seleranya oleh seseorang teman yang akrab. Ketiga, orang diajak bemlang ulang menghadiri kebaktian keagamaan. Keempat, selama waktu mencari pegangan baru orang mendapat anjuran dari saudara-saudaranya atau teman dekatnya . Kelima, sebelum bertobat ada 
sebuah jalinan hubungan dengan pemimpin agama tertentu.

Dari uraian faktor-faktor di atas Heirich mengungkapkan bahwa bukan selalu karena penyebab tunggal, tetapi adanya kerja sama (kombinasi) dari sejumlah faktorlah yang memberi pengaruh lebih kuat untuk mengubah pendirian seseorang berpindah atau masuk agama. Dengan kata lain, perpindahan agama sebagai fakta adalah suatu hasil dari suatu komplek jalinan pengaruh yang saling bantu membantu.

Pada dasamya konversi agama terjadi pada seseorang dikarenakan oleh adanya kebutuhan-kebutuhan hidup sebagai mahluk sosial atau dinamis tidak dapat terpenuhi secara wajar atau tidak bisa terjamin dengan layak. Di dalam suatu teori sosial dikatakan bahwa manusia adalah mahluk hidup yang dinamis (Hendropuspito, 1984). Untuk memenuhi kebutuhannya maka seseorang harus mengusahakannya dan belajar dari lingkungannya di mana ia berada. Ketika kebutuhan tersebut tidak dapat terpenuhi maka memungkinkan seseorang atau kelompok untuk berpindah - pindah tempat hingga dapat terpenuhi.

Demikian halnya dengan agama, jika seseorang merasakan tidak terpenuhi dalam dirinya berkaitan dengan apapun itu misalnya nilai, maka orang akan melakukan pindah agama dari satu agama ke agama lain. Dalam hal itu agama sebagai institusi kelompok sosial (religius) merupakan salah satu tempat yang final bagi orang untuk mencari nilai-nilai yang dapat menjamin kebutuhannya tersebut di tengah -tengah masyarakat yang selalu dapat saja berubah (Sulaiman, 1989).

William James (dalam Daradjat, 1979) mengatakan konversi agama banyak menyangkut masalah kejiwaan dan pengaruh lingkungan tempat berada. Konversi agama sebagai semacam pertumbuhan atau perkembangan spiritual yang mengandung perubahan arah yang cukup berarti, dalam sikap terhadap ajaran dan tindak agama. Konversi agama menunjukkan bahwa suatu perubahan emosi yang tiba-tiba ke arah mendapat hidayah Allah SWT secara mendadak, telah terjadi, yang mungkin saja sangat mendalam atau dangkal, dan mungkin pula terjadi perubahan tersebut secara berangsur-angsur.

Konversi agama banyak menyangkut masalah kejiwaan dan mempengaruhi lingkungan tempat berada. Selain itu, konversi agama yang dimaksudkan uraian di atas memuat beberapa pengertian dengan ciri-ciri:

- Adanya perubahan arah pandangan dan keyakinan seseorang terhadap agama dan kepercayaan yang dianutnya.

- Perubahan yang terjadi dipengaruhi kondisi kejiwaan sehingga perubahan dapat terjadi secara berproses atau secara mendadak. 
- Perubahan tersebut bukan hanya berlaku bagi perpindahan kepercayaan dari suatu agama ke agama lain, tetapi juga termasuk perubahan pandangan terhadap agama yang dianutnya sendiri.

- Selain faktor kejiwaan dan kondisi lingkungan maka perubahan itu pun disebabkan faktor petunjuk dari Yang Mahakuasa.
Fenomena Konversi Agama di Kota Pekanbaru

Agama terbesar di kota pekanbaru ialah agama Islam dengan komposisi penduduk secara etnis didominasi oleh etnis Melayu. Etnis lain juga menempati kota ini seperti: Mandailing, Minang, batak, Jawa, bugis, $\mathrm{Ocu}$, dan lain-lain. Diikuti dengan penganut agama terbesar kedua yaitu Kristen, selanjutnya Budha, Katolik, Konghucu, dan lain-lain.

Tabel 4.2

Jumlah Tempat Peribadatan Menurut Kecamatan Di Kota Pekanbaru, 2017

\begin{tabular}{|l|c|c|c|c|c|c|}
\hline \multicolumn{1}{|c|}{ Kecamatan } & Mesjid & Musholla & $\begin{array}{c}\text { Gereja } \\
\text { protestan }\end{array}$ & $\begin{array}{c}\text { Gereja } \\
\text { katolik }\end{array}$ & Pura & vihara \\
\hline Tampan & 170 & 67 & 20 & 1 & - & 2 \\
\hline Payung Sekaki & 42 & 30 & 14 & 1 & - & 9 \\
\hline Bukit Raya & 60 & 70 & 10 & - & - & 2 \\
\hline Marpoyan Damai & 115 & 35 & 15 & - & 1 & - \\
\hline Tenayan Raya & 117 & 135 & 25 & 3 & - & - \\
\hline Lima Puluh & 23 & 16 & 11 & - & - & 3 \\
\hline Sail & 17 & 7 & 10 & - & - & - \\
\hline Pekanbaru Kota & 21 & 12 & 13 & 1 & - & - \\
\hline Sukajadi & 37 & 16 & 15 & 1 & - & 2 \\
\hline Senapelan & 22 & 20 & 12 & - & - & - \\
\hline Rumbai & 38 & 39 & 26 & 3 & - & 1 \\
\hline Rumbai Pesisir & 50 & 45 & 15 & - & - & - \\
\hline Jumlah & 716 & 492 & 186 & 10 & 1 & 19 \\
\hline
\end{tabular}

Sumber: BPS Kota Pekanbaru, 2016

Dari tabel diatas dijelaskan bahwa, jumlah Masjid di Kecamatan Tampan sebayak 170, Musholla 67, Gereja Protestan 20, Gereja Katolik 1, Vihara 2. Payung Sekaki Masjid 42, Musholla 30, Gereja Protestan 14, Gereja Katolik 1, Vihara 9.Bukit Raya Masjid 60, Musholla 70, Gereja Protestan 10, Vihara 2. Marpoyan Damai Masjid 115, Musholla 35, Gereja Protestan 15, Pura 1. Tenayan
Raya Masjid Sebanyak 117, Musholla 135, Gereja Protestan 25, Gereja Katolik 3.

Lima Puluh Masjid Sebanyak 23, Musholla 16, Gereja Protestan 11, Vihara 3. Sail Masjid Sebanyak 17, Musholla 7, Gereja Protestan 10. Pekanbaru Kota Masjid Sebanyak 21, Musholla 12, Gereja Protestan 13, Gereja Katolik 1. Sukajadi Masjid Sebanyak 37, Musholla 16, Gereja 
Protestan 15, Gereja Katolik 1, Vihara 2. Senapelan Masjid Sebanyak 22, Musholla 20, Gereja Protestan 12. Rumbai Masjid Sebanyak 38, Musholla 39, Gereja Protestan 26, Gereja Katolik 3, Vihara 1.

Rumbai Pesisir Masjid Sebanyak 50, Musholla 45, Gereja Protestan 15. Jadi, jumlah keseluruhan tempat peribadatan menurut kecamatan sebanyak 1.424, diantaranya meliputi mesjid sebanyak 716 , musholla 492, gereja protestan 186, gereja katolik 10, pura 1, dan vihara 19. Dengan demikian dapat disimpulkan bahwa tempat peribadatan yang paling banyak adalah Mesjid dan diikuti oleh Musholla, Gereja Protestan, Gereja Katolik,Vihara, danPura.

Tabel 4.15

Rekapitulasi Data Konversen Lima Tahun Terakhir

Data Dari Tahun 2013-2017

\begin{tabular}{|l|c|c|c|c|c|c|c|}
\hline \multicolumn{1}{|c|}{ Kecamatan } & $\mathbf{2 0 1 3}$ & $\mathbf{2 0 1 4}$ & $\mathbf{2 0 1 5}$ & $\mathbf{2 0 1 6}$ & $\mathbf{2 0 1 7}$ & $\begin{array}{c}\text { Jumla } \\
\mathbf{h}\end{array}$ & $\begin{array}{c}\text { Persenta } \\
\text { se }\end{array}$ \\
\hline Tampan & 10 & 15 & 18 & 22 & 37 & 102 & $\mathbf{1 2 , 7 9}$ \\
\hline Payung Sekaki & 12 & 16 & 13 & 15 & 25 & 81 & 10,16 \\
\hline Bukit Raya & 11 & 14 & 17 & 23 & 25 & 90 & 11,28 \\
\hline $\begin{array}{l}\text { MarpoyanDam } \\
\text { ai }\end{array}$ & 9 & 11 & 15 & 23 & 35 & 93 & $\mathbf{1 1 , 6 6}$ \\
\hline Sail & 4 & 7 & 15 & 18 & 23 & 67 & 8,40 \\
\hline $\begin{array}{l}\text { Pekanbaru } \\
\text { Kota }\end{array}$ & - & 9 & 3 & 5 & 11 & 28 & 3,51 \\
\hline Sukajadi & 8 & 10 & 17 & 20 & 25 & 80 & 10,03 \\
\hline Senapelan & 5 & 9 & 12 & 20 & 28 & 74 & 9,28 \\
\hline Rumbai & 1 & 30 & 32 & 35 & 22 & 120 & $\mathbf{1 5 , 0 5}$ \\
\hline Rumbai Pesisir & 4 & 8 & 13 & 17 & 20 & 62 & 7,77 \\
\hline \multicolumn{1}{|c|}{ Jumlah } & $\mathbf{6 4}$ & $\mathbf{1 2 9}$ & $\mathbf{1 5 5}$ & $\mathbf{1 9 8}$ & $\mathbf{2 5 1}$ & $\mathbf{7 9 7}$ & $\mathbf{1 0 0} \mathbf{\%}$ \\
\hline
\end{tabular}

Sumber: Olahan Data 2018

Rekapitulasi data konversen lima tahun terakhir Kota Pekanbaru pada tahun 2013 sebanyak 64 orang, pada tahun 2014 sebanyak 129 orang, pada tahun 2015 sebanyak 155 orang, pada tahun 2016 sebanyak 198 dan pada tahun 2017 sebanyak 251 orang. Berdasarkan jumlah diatas maka peningkatan konversen di kota pekanbaru dari tahun 2013-2017 mengalami peningkatan sebanyak 797 konversen.
Berdasarkan data tersebut dapat kita lihat bahwa kecamatan yang mengalami peningkatan konversi agama dari agama non Islam ke Islam yang tertinggi dari tahun 2013-2017 terjadi di Kecamatan Rumbai, diikuti Kecamatan Tampan, Marpoyan Damai, Tenayan Raya, Bukit Raya, Payung Sekaki, Sukajadi, Senapelan, Lima Puluh,Sail, Rumbai pesisir, dan yang paling rendah adalah kecamatan Pekanbaru Kota.

Makna Konversi bagi Konversen 
Proses konversi agama dapat diumpamakan seperti proses pemugaran gedung, bagunan lama yang dibongkar dan pada tempat yang sama didirikan bagunan baru yang lain sama sekali dari bangunan sebelumnya. Demikian seseorang atau kelompok masyarakat yang mengalami proses konversi agama ini. Segala bentuk kehidupan batinnya pada awalnya mempunyai pola tersendiri berdasarkan pandangan hidup yang dianutnya, maka setelah terjadi konversi agama pada dirinya secara spontan pula lama ditinggalkan sama sekali (Daradjat, 2005).

Segala bentuk perasaan batin terhadap kepercayaan lama, seperti : harapan, rasa bahagia, keselamatan, dan kemantapan berubah menjadi berlawanan arah. Timbullah gejala-gejala baru berupa perasaan serba tidak lengkap dan tidak sempurna. Gejala ini menimbulkan proses kejiwaan dalam bentuk merenung, timbulnya tekanan batin penyesalan diri, rasa berdosa, cemas terhadap masa depan dan perasaan susah yang ditimbulkan oleh kebimbangan (Ramayulis, 2002). Manusia memerlukan ketentraman batin, kebahagian dan kepastian masa depan. Manusia akan mengalami kekosongan batin yang membuatnya asing dan kesepian dalam kegaduhan dan kesemarakan dunia modern. Manusia memerlukan sesuatu yang bersifat maknawi yang mampu memberikan makna kekinian dan keseniannya.Dan ini hanya dimiliki oleh agama (Ali, 1981). Demikian pula, agama berperan juga sebagai unsur sublimatif yang memberi makna kedalaman dan sekaligus ketinggian pada kehidupan duniawi manusia, baik sebagai makhluk individu maupun sebagai makhluk sosial.

Sebagai hasil dari pemilihannya terhadap pandangan hidup itu maka ia bersedia dan mampu untuk membaktikan diri kepada tuntunan-tuntunan dari peraturan, ada dalam pandangan hidup yang dipilihnya itu berupa ikut serta berpartisipasi secara penuh. Makin kuat keyakinan terhadap kebenaran pandangan hidup itu semakin tinggi pula nilai bakti yang diberikannya. Dengan demikian manusia mampu memberikan perubahan terhadap apa yang dipilihnya dan merasa puas dalam menjalani kehidupan berikutnya.

Melalui proses konversi agama pada diri seseorang, Sebagai hasil dari konversi agama itu sering kali seseorang menemukan dirinya mempunyai pemahaman yang baik akan kemantapan keagamaan hingga dewasa atau matang dalam beragama. Kematangan atau kedewasaan seseorang dalam beragama biasanya ditunjukkan dengan kesadaran dan keyakinan yang teguh atau istiqomah. Karena menganggap kebenaran agama yang dianutnya adalah agama yang sempurna dan diperlukan dalam kehidupannya.

Berdasarkan dokumen Surat Keterangan Masuk Islam (SKMI) di Kantor Urusan Agama (KUA) di berbagai 
Kecamatan di lingkungan Kota Pekanbaru, dapat ditemukan pada bagian motivasi bahwa yang menjadi pendorong para konversen melakukan konversi antara lain; keinginan sendiri/niat dari hati, dan agar bisa menikah/ikut agama calon suami. Dari hampir 100 lembar dokumen SKMI yang telah diperiksa jawaban terbanyak yang diberikan oleh konversen terhadap item boring yang mempertanyakan motif adalah; niat dari hati/keinginan sendiri. Hal ini terasa kurang mewakili untuk mencari penjelasan tentang makna konversi bagi konversen.

Berdasarkan penjelasan responden dalam wawancara tentang latar belakan tindakan mereka melakukan konversi agama di kota pekanbaru disebabkan oleh beberapa faktor antara lain :

\section{Cinta dan Pernikahan}

Loris Nolin memantapkan dirinya untuk melakukan konversi agama setahun lalu. Faktor yang melatar belakangi konversi yang dilakukan Nolin adalah cinta.. Beliau melakukan konversi agama pada usia 25 tahun. Pendidikan terakhir Nolin, adalah tamatan SMP, Beliau tinggal di Jalan Kutilang, di lingkungan masyarakat mayoritas Islam. Pada tanggal 23 februari 2016. Nolin pindah agama disebabkan karena ia menjalin hubungan dengan kekasihnya yang beragama Islam. Nolin memutuskan untuk menikah dengan kekasihnya. Kehidupan rumah tangganya di awal pernikahannya berjalan lancar dan bahagia. Keluarga Nolin tidak mengucilkan dirinya. Mereka menganggap itu keputusan dan hak yang ia pilih.

Kemudian 3 bulan terakhir ini kehidupan rumah tangga mereka kurang harmonis. Mereka sempat bertengkar dan pisah selama 3 bulan dengan catatan tidak bercerai. Akan tetapi Nolin dan suami kini menjalin hubungan dengan baik sampai sekarang. Mereka memutuskan untuk hidup rukun dan kembali menjalin hubungan suami istri yang harmonis. Agama yang dipilih Nolin sekarang berperan penting dalam kehidupan keluarganya. Nolin sudah mulai biasa dan menerima tuntutan dan kewajiban dalam kehidupan agama yang dipilihnya (Noni, Wawancara, 2018). "Perasaan saya setelah menjadi konversen jauh lebih bahagia, dan tentram suami saya sudah menerima keadaan saya, mengerti ketika saya di ajari tentang ibadah dan aqidah agama Islam. Ekonomi saya baik setelah memilib cinta dan menikah dengan suami saya." (Noni, Wawancara, 2018).

Murni melakukan konversi agama pada usia 28 tahun, beliau bekerja sebagai tukang ojek. Konversi agama yang dilakukakan oleh murni disebabkan oleh faktor cinta. Beliau mengatakan tidak ada paksaan terhadapnya untuk melakukan konversi. Proses pindah agama yang terjadi pada murni dalam keadaan 
tenang. Hanya saja ketika ijab kabul beliau sedih karena tidak dihadiri kedua orang tuanya. Proses awal murni mengalami penyesalan setelah pindah agama, ada perasaan berontak dalam dirinya (Murni, Wawancara, 2018).

Ketika suami menyuruhnya untuk sholat ia tidak mau, sering ada perbedaan pendapat karena masih terpengaruh dengan agama yang lama. Terkadang, ketika beliau pulang kerumah orang tuanya, ia masih mau pergi kegereja tetapi, diawal proses yang dialaminya, Sempat orang tua menyuruh beliau cerai dan masuk agama Kristen lagi. Begitu banyak cobaan yang dialami Murni dalam proses ini.

Akan tetapi berkat dukungan dari suami lama kelamaan beliau terbiasa dengan agama Islam ditambah lagi dalam pergaulan dengan masyarakat yang beragama Islam menambah keyakinannya kuat. Seperti ikut pengajian dan arisan yang menambah wawasan dalam mempelajari dan mendalami agama Islam. Awalnya orang tua tidak mendukung tetapi, Setelah dikarunia anak, kedua orang tua pasrah dengan pilihan yang ia ambil. Orang tua juga sempat berkata "Nasi sudah menjadi bubur jadi bagaimana agar bubur itu enak dimakan.” Semakin mantap keyakinan beliau dalam agama Islam sampai sekarang. Hingga akhirnya beliau merasa tenang.
Kepuasan terhadap keputusan yang sudah diambil membawa suasana batin menjadi mantap sebagai pernyataan menerima konsep baru. Aspek yang membuat murni tertarik untuk meninggalkan kepercayaan yang lama ialah kemauan dan cinta. Kemauan yang timbul pada diri murni membuat Beliau memutuskan untuk menikah dan pindah agama. Setelah banyak proses yang dialami, Murni berkata bahwa Agama Islam berperan penting dalam proses yang dialaminya ia merasa kuat dan pasrah setelah berteman dengan teman-teman di daerah perumahannya yang beragama islam dan beliau merasa yakin dan menuruti semua perintah suaminya (Murni, Wawancara, 2018). Kehidupan ekonomi konversen sekarang sejahtera, beliau kini tidak bekerja sebagai ojek lagi, sebab pendapatan suami cukup untuk kehidupan sehari-hari.

Lili RT 01. RW 06 Kelurahan Simpang Baru, saya mengenali Murni sebagai masyarakat di daerah kelurahan tempat beliau tinggal. Faktor yang menyebabkan Murni pindah agama karena cinta dan pernikahan. Sekarang Murni aktif dalam kegiatan pengajian dan PKK, serta tidak malu dalam megikuti kegiatan-kegiatan yang berhubungan dengan masyarakat dan keagamaan. Murni seorang konversen yang memiliki semangat tinggi, saya melihat bahwa Murni sosok muallaf yang ceria dan tampil apadanya. Beliau 
dapat menerima masukan dan tanggapan dari siapapun yang menilai dirinya (Lili, Wawancara, 2018).

Dari kisah Nolin dan Murni, penulis menyimpulkan bahwa makna konversi yang dirasakan oleh konversen adalah "legalisasi" dari hubungan cinta dan kasih sayang dengan kekasih beda agama, sekaligus upaya menempatkan diri beradaptasi agar bias diterima lingkungan. Upaya-upaya tersebut dijalani dalam rangka mendapatkan ketenangan batin.

Tindakan Pindah agama yang berawal dari cinta dan pernikahan sekilas terkesan tidak tulus. Selain itu hal tersebut juga menimbulkan konflik dalam hubungan dengan keluarga konversen. Akan tetapi bersama berjalannya waktu terjadi perubahan secara perlahan-lahan. pengenalan terhadap agama baru yang semakin lama semakin baik, mengalihkan kecintaan yang tadinya hanya pada pasangan berubah menjadi kecintaan terhadap agama dan komunitas (umat). Peralihan orientasi rasa itu membawa perubahan-perubahan yang signifikan pula pada kepribadian dan tingkah laku konversen menjadi lebih matang dan lebih simpatik, sehingga dengan demikian secara perlahan-lahan dapat mengubah hubungan dengan keluarga asal yang awalnya mengalami konflik menjadi rukun kembali.
2. Pengaruh Lingkungan

Laurina Salmon menceritakan kisah perpindahan yang dialaminya sekitar dua tahun yang lalu. Laurina pindah dari agama Katolik ke agama Islam pada usia 36 tahun. Beliau tinggal di Cipta Karya bersama kedua orang tuanya. Laurina Salmon bekerja di Toko Bagunan (Salmon, Wawancara, 2018).

Ketika Laurina memakai hijab terlihat lebih anggun, mulai saat itu ia memantapkan dirinya untuk pindah ke agama Islam. Kemudian teman-teman kantornya mendukung kemauan yang ia sampaikan kepada mereka. Jadi Laurina benar-benar ingin pindah dan menjalankan keyakinan yang ia pilih sampai sekarang. Sejauh yang penulis lihat proses yang terjadi melalui faktor sugesti dari teman karib berperan penting dalam perpindahan ini.

Laurina mengalami konflik batin yang berat saat memutuskan untuk melakukan konversi. Ia merasa telah menyakiti perasaan keluarganya dengan keputusan tersebut. Itulah sebabnya ia membuat perencanaan yang hati-hati sebelum melakukan tindakan tersebut. Dalam tahapan ini terkesan ada keraguan yang mewarnai keinginannya. Akan tetapi ternyata dorongan sugesti dari lingkungan membawanya menemukan pemantapan bahwa apa yang ia rencanakan bukanlah sesuatu yang sia-sia. Laurina merasakan adanya 
suatu tenaga jiwa atau perasaan yang menguasai pusat kebiasaannya, sehingga pada dirinya muncul persepsi baru dalam bentuk suatu ide yang bersemi secara mantap.

Makna konversi bagi Laurina adalah pengorbanan besar berupa rasa bersalah karena melukai perasaan keluarga. Pengorbanan yang dilakukan demi mendapatkan sesuatu yang lebih besar, yakni ketentraman batin dan kemantapan jiwa menjalani hidup dalam kebenaran.

Bagi Muhammad Sholeh, pindah agama adalah suatu upaya untuk mendapatkan penerimaan dan perlindungan. Kedua orang tua Mohammad Sholeh beragama Kristen. Kehidupan keluarga Mohammad Sholeh tidak harmonis, orang tuanya pisah. Ibu bapaknya menelantarkan Sholeh (Wawancara, 2018). Kemudian ia diasuh oleh bibinya. Mohammad sholeh diajak oleh bibinya untuk pindah ke agama Islam. Mohammad Sholeh menerimanya dan kini hidup bersama bibinya. Mulai dari biaya kehidupan, biaya SD, MDA, dan lainlain dibiayai oleh bibi Muhammad Sholeh (Rita, Wawancara, 2018).

Togar Siregar menyebutkan hal yang sama dengan informan lainnya. Semangat masyarakat di wilayah perumahan permata bunda tempat beliau tinggal sangat positif. Masyarakat menerima muallaf dengan sangat ramah.
Masyarakat memberikan hadiah seperti seperangkat alat sholat dan buku tentang ibadah. Adik beliau juga seorang muallaf, pindah agama disebabkan oleh faktor pernikahan. Tetapi adik beliau tidak tinggal di daerahnya. Setelah menikah ikut dengan suaminya. Beliau kenal dengan Erma B Manalu sebagai muallaf di daerah tempat ia tinggal. Setelah menjadi muallaf Pak Togar gigih dan penuh semangat mendakwahkan Islam di kalangan keluarga dan kerabatnya yang non muslim (Togar, Wawancara, 2018).

Pengaruh lingkungan yang kondusif dan positif dalam penerimaan muallaf memberikan makna bagi Togar bahwa konversi dapat membawa perbaikan dan keharmonisan dalam kehidupan masyarakat. bagi pribadi yang optimis seperti Togar, sesuatu yang memang diniatkan harus diusahakan dan diperjuangkan secara totalitas.

3. Hidayah

Rinto Situmorang memantapkan dirinya untuk pindah agama pada usia 28 tahun, disebabkan oleh faktor hidayah. Beliau mengaku tidak pernah diajak, dirayu, dan dipaksa oleh siapapun. Kemauan Rinto masuk Islam karena pengalaman beragama. Selama merantau di Rokan Hulu, ia merasa tenang dan merasa terpanggil ketika mendengar suara azan. 
Setelah pindah agama, Rinto menemukan makna dari cobaan hidup yang ia alami adalah semata-mata sebagai sarana untuk membersihkan dirinya dari dosa di masa lalu (Sitomurang, Wawancara, 2018).

Konversen Erma B Manalu memilih pindah agama pada usia 26 tahun, disebabkan karena hidayah. Pada saat SD beliau sudah mulai menyukai membaca dan menonton filem Hidayah. Tetapi, beliau memantapkan diri untuk pindah agama setelah menikah. Keyakinan itu bertambah mantap setelah mendengarkan ceramah di TV tentang agama Islam.

Setelah melakukan konversi, Erma juga banyak mendapatkan cobaan hidup. Erma sempat tidak dianggap sebagai anak dan berkelahi dengan orang tuanya. Orang tua sedih dan marah karena anaknya pindah agama. Tetapi setelah 4 bulan berdoa kedua orang tua menerima beliau sebagai anaknya. beliau berkata setelah menjadi muallaf kehidupan beliau bahagia. Erma merasa bahwa sejak menjadi muallaf, apa saja yang ia minta dalam doa nya InsyaAllah dikabulkan (Sitomurang, Wawancara, 2018).

Ismail, yang memiliki nama asli Cao Duy Kanh, merupakan seorang muallaf asal Vietnam yang baru saja menamatkan kuliah di jurusan Ilmu AlQur'an dan Tafsir program Internasional UIN Suska Riau.
Sebelum melakukan konversi ke agama Islam, Ismail beragama Bani. Tujuh tahun yang lalu Cau menjadi muallaf atas ajakan pamannya. Kebosanan akan cara hidup yang tak menentu di tengah komunitas Bani di kampungnya membuat Cao resah dan berfikir mendalam tentang makna kebenaran yang sesungguhnya. Pamannya yang sudah lebih dulu mengenal Islam selama merantau, selalu mendiskusikan Islam dengannya dan merancang kemungkinan untuk sama sama pindah ke agama Islam. Namun ternyata dalam perjalanan kisahnya Cao lebih dulu menyatakan kesiapan untuk menjadi muallaf pada tahun 2011, sementara pamannya baru mengikuti langkahnya tiga tahun setelah itu. Meski masih belum memahami keseluruhan ajaran Islam secara total Cao berani membawa ayah ibu dan adik adiknya untuk mengikuti langkahnya memeluk Islam. Namun hal tersebut tak semudah membalikkan telapak tangan.

Di awal konversinya, orang tuanya menentang habis-habisan dan bersikap membencinya karena tindakannya itu dinilai melanggar tradisi dan merusak tatanan masyarakat di kampungnya yang secara keseluruhan beragama Bani. Meski agama Bani adalah agama sinkretistik yang mencapur adukkan ajaran Hindu dan Islam, namun masyarakat Bani sangat tidak menyukai Islam. Sepanjang diskusi keagamaan mereka dapat menerima kebenaran 
Islam namun mereka sama sekali tidak suka bila diajak masuk Islam. Bagi masyarakat Bani, agama Bani adalah identitas utama mereka terkait penghormatan terhadap tradisi dan pemujaan nenek moyang (Ismail, Wawancara, 2018). Sebagai hasilnya hingga saat ini, orang tuanya belum mau masuk Islam, meskipun sudah bisa menerima keputusan anaknya yang melakukan konversi pindah ke agama Islam. Bahkan adik bungsunya yang perempuan juga sudah mengikuti jejaknya masuk Islam dan orang tuanya menerima keputusan mereka serta tetap membiayai perkuliahan mereka. Sementara adik laki lakinya yang nomer dua juga masih beragama Bani.

Bagi seorang Cao, konversi masuk Islam merupakan perjuangan demi kebenaran. Seorang pemuda yang jernih berfikir tentang agama yang benar dan memperjuangkannya dengan cara apapun. Ada kerisauan dalam jiwanya bahwa suatu hari ketika dia pulang ke negerinya yang diperintah dibawah ideologi komunisme, dia akan menghadapi kesulitan kesulitan yang makin banyak. Di Vietnam orang tak boleh mengembangkan agamanya baik dari segi pendidikan maupun bidang lainnya. Pelaksanaan agama dibolehkan secara amat terbatas. Sulit mendapatkan makanan halal atau boleh dikatakan tidak ada sama sekali, karena orang boleh makan apa saja. Bila seseorang ingin mendapatkan ayam yang disembelih atas nama Allah, maka ia harus melakukannya sendiri. Di kalangan masyarakat Bani di kampungnya pun, orang memakan makanan sesuka hati. Hanya para Achan yang makan makanan dengan menyembelihnya terlebih dahulu. Sementara bagi orang awam mereka makan apa saja tanpa adanya keharusan untuk menyembelih. Dan bila ada yang menolak makanan yang mereka tawarkan, mereka akan tersinggung. Banyak kasus, di mana muallaf dari kalangan Bani setelah pulang ke masyarakatnya kembali lagi mengikuti cara hidup a la Bani karena tidak tahan dengan tekanan hidup yang di hadapi, mereka dihina, dibenci dan tak jarang mendapatkan kekerasan fisik bahkan terkadang dibunuh. Kebencian masyarakat Bani terhadap anggota yang melakukan konversi biasanya karena alasan harga diri sebagai komunitas. Sedangkan bagi Pemerintah Komunis Vietnam sendiri lebih dikarenakan alasan politis berhubung Islam (dan juga Kristen) adalah "agama luar” yang berkemungkinan akan merusak tatanan masayarakat sosialis mereka yang berideologi tertutup.

Sedemikian rupa beratnya tantangan yang harus dihadapi oleh seorang Cao demi mempertahankan keyakinan barunya itu, namun demikian dia bertekad untuk tak menyerah dan akan mempertahankan iman Islamnya sampai kapanpun. "Saya sudah 
berkorban banyak demi meraih hidayah ini, mana mungkin akan saya tinggalkan begitu saja" ungkap Cao (Wawancara, 2018).

Zakiah Daradjat memberikan pendapatnya bahwa proses konversi agama melalui 5 tahap yaitu:

1. Masa tenang; di saat ini kondisi seseorang berada dalam keadaan yang tenang karena masalah agama belum mempengaruhi sikapnya.

2. Masa ketidak tenangan, tahap ini berlangsung jika masalah agama telah mempengaruhi batinnya.

3. Masa konversi, tahap ketiga ini karena terjadi setelah konflik batin mengalami keredaan karena kemantapan batin telah terpenuhi berupa kemampuan menentukan keputusan untuk memilih sesuatu yang dianggap serasi ataupun timbulnya rasa pasrah.

4. Masa tenang dan tentram yang kedua ini berbeda dengan tahap yang sebelumnya. Jika pada tahap yang pertama keadaan itu dialami karena sikap acuh tak acuh, maka ketenangan dan ketentraman pada tahap ketiga ini ditimbulkan oleh kepuasaan terhadap keputusan yang sudah diambil.

5. Masa ekspresi konversi, sebagai ungkapan dari sikap menerima, terhadap konsep baru dari ajaran agama yang diyakininya, maka tindak tanduk dan sikap hidupnya diselaraskan dengan ajaran dan peraturan agama yang dipilih tersebut.

Menurut Wasyim proses konversi agama dibagi menjadi tiga yaitu:

1. Masa gelisah, kegelisahan atau ketidaktenangan karena adanya jarak antara seseorang yang beragama dengan Tuhan yang disembah. Ditandai dengan adanya konflik dan perjuangan mental aktif.

2. Adanya rasa pasrah.

3. Pertumbuhan secara perkembangan yang logis, yakni, tampak adanya realisasi dan ekspresi konversi yang dialami dalam hidupnya.

Proses tersebut boleh jadi karena melalui proses konversi agama pada diri seseorang atau karena berbarengan dengan kematangan kepribadiannya. Sebagai hasil dari konversi, sering kali seseorang menemukan dirinya mempunyai pemahaman yang baik akan kemantapan keagamaannya hingga matang dalam beragama. Istilah konversi agama sudah tidak asing lagi kita dengar.Mulai dari kalangan masyarakat biasa sampai pada kalangan intelektual.Konversi agama menyangkut perubahan batin seseorang secara mendasar.

\section{Kesimpulan}

Konversi agama yang terjadi pada masyarakat kota pekanbaru sebanyak 797 orang dari tahun 2015-2017. Pola umum dalam peristiwa konversi agama di Pekanbaru antaralain; konversi yang 
dilatarbelakangi pernikahan. Fenomena seperti ini bisa terjadi pada pihak wanita (istri) atau laki-Iaki (suami). Seorang anak yang pindah agama karena keretakan keluarganya. Seorang pekerja yang rela mengubah keyakinan karena tertarik dengan hijab. Seorang pemuda yang tertarik pindah agama karena mendengar suara azan. Seorang wanita yang tertarik pindah agama karena membaca dan menonton film Hidayah. Fenomena konversi agama merupakan hal yang dapat mengubah pendirian atau keyakinan seseorang dari agama sebelumnya pindah ke agama lain. Fenomena ini dapat meresahkan hati dan keyakinan dari setiap pemeluk agama.Termasuk pemeluk agama yang berada di Kota Pekanbaru.

Proses konversi agama dapat diumpamakan seperti proses pemugaran gedung, bagunan lama yang dibongkar dan pada tempat yang sama didirikan bagunan baru yang lain sama sekali dari bangunan sebelumnya. Demikian seseorang atau kelompok masyarakat yang mengalami proses konversi agama ini. Segala bentuk kehidupan batinnya pada awalnya mempunyai pola tersendiri berdasarkan pandangan hidup yang dianutnya, maka setelah terjadi konversi agama pada dirinya secara spontan pula lama ditinggalkan sama sekali.

Segala bentuk perasaan batin terhadap kepercayaan lama, seperti : harapan, rasa bahagia, keselamatan, dan kemantapan berubah menjadi berlawanan arah. Timbullah gejala-gejala baru berupa perasaan serba tidak lengkap dan tidak sempurna. Gejala ini menimbulkan proses kejiwaan dalam bentuk merenung, timbulnya tekanan batin penyesalan diri, rasa berdosa, cemas terhadap masa depan dan perasaan susah yang ditimbulkan oleh kebimbangan. Manusia memerlukan ketentraman batin, kebahagian dan kepastian masa depan. Manusia akan mengalami kekosongan batin yang membuatnya asing dan kesepian dalam kegaduhan dan kesemarakan dunia modern. Manusia memerlukan sesuatu yang bersifat maknawi yang mampu memberikan makna kekinian dan keseniannya.Dan ini hanya dimiliki oleh agama. Demikian pula, agama berperan juga sebagai unsur sublimatif yang memberi makna kedalaman dan sekaligus ketinggian pada kehidupan duniawi manusia, baik sebagai makhluk individu maupun sebagai makhluk sosial.

Sebagai hasil dari pemilihannya terhadap pandangan hidup itu maka ia bersedia dan mampu untuk membaktikan diri kepada tuntunan-tuntunan dari peraturan, ada dalam pandangan hidup yang dipilihnya itu berupa ikut serta berpartisipasi secara penuh. Makin kuat keyakinan terhadap kebenaran pandangan hidup itu semakin tinggi pula nilai bakti yang diberikannya. Dengan demikian manusia mampu memberikan perubahan terhadap apa yang dipilihnya dan merasa puas dalam menjalani kehidupan berikutnya. 
Melalui proses konversi agama pada diri seseorang, Sebagai hasil dari konversi agama itu seringkali seseorang menemukan dirinya mempunyai pemahaman yang baik akan kemantapan keagamaan hingga dewasa atau matang dalam beragama. Kematangan atau kedewasaan seseorang dalam beragama biasanya ditunjukkan dengan kesadaran dan keyakinan yang teguh atau istiqomah.

Karena menganggap kebenaran agama yang dianutnya adalah agama yang sempurna dan diperlukan dalam kehidupannya.

Faktor-faktor penyebab terjadinya konversi agama di Pekanbaru adalah faktor cinta dan pernikahan, pengaruh lingkungan dan hidayah. Di kecamatan Tampan, Dari keseluruhan faktor tersebut yang dominan terjadi pada faktor cinta dan pernikahan. Diikuti dengan kecamatan Marpoyan Damai, Pekanbaru Kota, Sukajadi, Tenayan Raya lebih dominan pada faktor, cinta pernikahan, pendidikan, hidayah. Kecamatan Bukit Raya, Senapelan, Lima Puluh, dan Sail lebih dominan pada faktor pendidikan, hidayah, cinta dan penikahan. Sedangkan kecamatan Rumbai dan Rumbai Pesisir lebih dominan pada faktor ekonomi, cinta dan pernikahan.

Di antara faktor-faktor tersebut yang paling dominan terjadi ialah karena faktor pernikahan. Ajakan dan cinta dari suami merupakan peran penting dalam faktor ini. Kemauan dari setiap muallaf untuk pindah menjadi dasar terjadinya faktor lain. Akan tetapi tanpa hidayah yang diberikan oleh Allah SWT tidak ada manusia yang dapat mengubah kemauannya untuk pindah agama. Hanya manusia pilihan yang mendapatkan hidayah dari-Nya.

Berdasarkan uraian-uraian hasil observasi dan wawancara diatas dapat diambil kesimpulan bahwa konversi agama bisa terjadi pada siapapun. Mulai dari seseorang yang taat pada agamanya sampai pada orang yang tidak peduli pada agama. Motif konversi agama pada masyarakat Kota Pekanbaru adalah cinta dan pernikahan, pendidikan, ekonomi, ajakan, dan hidayah. Hanya sedikit pelaku konversi yang pindah agama karena hasil dari pengalaman yang benar-benar karena ingin mencari ridho ilahi. Hal ini terlihat dari data-data yang telah penulis sajikan. Implikasi dari ini maka para pelaku konversi tersebut kurang sunguh-sungguh dalam menjalankan ajaran Islam.

Namun seiring dengan perjalanan waktu tercipta interaksi yang baik antara pelaku konversi dengan komunitas agama barunya memberikan pemahaman yang benar dan memberi makna yang positif dalam proses konversi yang terjadi. Pembauran dan penerimaan komunitas terhadap pelaku konversi menjadi faktor utama yang membantu pelaku untuk menemukan stabilitas dalam proses konversi yang sedang dijalaninya 


\section{DAFTAR PUSTAKA}

M. Arifin. Psikologi dan Beberapa Aspek Kebidupan Manusia. Bulan Bintang : Jakarta,1990.

Abdul FatahRohadi. Sosiologi Agama. CV Titian Kencana Mandiri : Jakarta, 2004.

Agusrianto, Al-Hikmah Jurnal Pendiikan dan Pemikiran Islam. Vol.1 No.2, Juli - Desember. LPPM STAI Kuantan Singingi.2009.

Ahamad Beni Saebani. Sosiologi Agama. PT Refika Aditama : Bandung.2007.

Ali Mukti.Beberapa Persoalan Agama Dewasa Ini. Rajawali : Jakarta. 1981.

ArikuntoSuharsimi. Prosedur Penelitian. Rineka Cipta : Jakarta, 2002.

Aripuddin Acep. Dakwah Antar Budaya. PT Remaja Rosdakarya : Bandung.2012.

Arnel Iskandar dan Hasbullah. Pedoman Penulisan Karya Ilmiah. Fakultas Ushuluddin Universitas Islam Negri Sultan Syarif Kasim Riau : Pekanbaru. 2015.

Daradjat Zakiah. Ilmu Jiwa Agama. Bulan Bintang : Jakarta. 2005.

Etta Mamang Sangadji. Sopiah MM. Metode Penelitian. ANDI : Yogyakarta.2010.

Farid Mohammad. Konversi Agama Dalam Masyarakat Melayu di NegeriJohorSkripsi S1,UIN Suska Riau.2013.

Hanafi. Dasar-Dasar Psikologi Agama. LPPM Uin Suska Riau: Pekanbaru. 2014.

Husaini Usman. Purnomo Setiady Akbar. Metodologi Penelitian Sosial, Bumi Aksara : Jakarta.2009.

Ishomuddin. Sosiologi Agam. Ghalia Indonesia : Malang.2002.
Jalaluddin. psikologi agama. PT Raja Grafindo Persada : Jakarta.2005.

John M. Echols dan Hassan Shadily. Kamus Inggris Indonesia. PT Gramedia Pustaka Utama : Jakarta.2005.

Kahmad Dadang. Sosiologi Agama. PT Remaja Rosdakarya : Bandung.2006.

Khotimah. Jurnal Ushuluddin. Agama dan Civil Society. Volume Xxi No 1 Januari 2014 Issn. 1412-0909.

Kriyantono Rahmat. Teknik Praktis Riset Komunikasi. Kanisius : Yogyakarta.1992.

Mardalis. Metode Penelitian Suatu Pendekatan Proposal. Bumi Aksara : Jakarta.1999.

Mulyana Dedi. Metode Penelitian Kualitatif. Remaja Rosyada Karya : Bandung.2002.

Nata Abuddin. Metodologi Studi Islam. Rajawali Pers : Jakarta.2009.

Ramayulis. Psikologi Agama. Kalam Mulia : Jakarta. 2002.

Sururin. Ilmu Jiwa Agama. PT Raja Grafindo Persada : Jakarta.2004.

Singarimbun Masri. dkk. Metode Survei. Cetakan Ke-10, 2003. LP3S : Jakarta.2010.

Syukri, Mahyudin. Agamadan Ekonomi. Suska Press : Pekanbaru. 2009.

Thamrin Husni. Dinamika Agama, Sosial dan Teknologi. Suska Press : Pekanbaru.2009.

Thouless Robert H. Pengantar Psikologi Agama. PT Raja Grafindo Persada : Jakarta.2000.

Yeli Salmaini. Psikologi Agama,Zanafa. Publishing : Pekanbaru.2012.

Http://Library.Walisongo.Ac.Id/Digilib/ Files/Disk1/76/Itptiain-Gdl- 
Khadirotul-3779-1-4102039 -

P.Pdf.

Http://Digilib.Uinsuka.Ac.Id/8315/1/Su

kiman $\% 20$ konversiagama $\% 20$ (Stu

di $\% 20$ kasus $\% 20$ pada $\% 20$ dua $\% 20$

keluarga $\% 20$ di $\% 20$ dusun $\% 20$ pase

kan $\% 20$ maguwoharjo,\%20depok,

\%20sleman).Pdf.

Http://Repository.Usu.Ac.Id/Bitstream/

123456789/37713/4/Chapter $\% 20$

ii.Pdf.

Http://Www.E-

Jurnal.Com/2013/11/Pengertian-

Peta-Menurut-Para-Ahli.Html.

Http://Eprints.Ums.Ac.Id/12427/2/Bab I.Pdf.

Https://Jurnal.Ugm.Ac.Id/Jurnal-

Humaniora/Article/View/948/79

$\underline{5}$

Vol. 10, No. 2, Juli - Desember 2018 